\title{
Communications in the Business Curriculum
}

\begin{abstract}
Good managers must have good communication skilis, but that means more than just writing a nice essay or making a clever speech. As a result, hospitality educators' view of communication mustbe expanded
\end{abstract}

\section{by Judi Brownell}

EFFECTIVE communication is es sential to effective management. The tools that managers need come down, in the final analysis, to in sight, understanding, and behavior. These tools can be addressed in meaningful ways in the communi cation classroom.

I contend that communication instruction that focuses exclusively on developing skills without regard for process, content, and context is largely misdirected. If students leave our communication courses for a life of effective writing and clear speaking, we are delighted in deed. The fact that these are the most obvious goals for our courses often creates the impression that they are also the most important goals. They may well have been so, in the past. Now, as communication educators contribute to preparing students to be leaders in the hospi tality field, we are becoming in creasingly concerned with the long-

JudiBrownell, Ph.D., is an assistant professor at the Cornell School of Hotel Administration. term view-with helping students become more responsible, and more effective, communicators.

In this article, I will discuss sev eral topics as each relates to the de velopment of future hospitality leaders. First, I will cover the culti vation of two characteristics-em pathy and trust - that encourage healthy organizational relation ships. Then I will examine the shift in management style from a di rective to a more participative approach, as it influences our understanding of a manager's com munication needs - particularly since the most effective managers are known for their coaching skills. I will also consider the role intui tion plays in effective management practice. Lastly, I will explain why I believe the communication class room is the appropriate setting for considering ethical issues, as stu dents explore the consequences and implications of the choices they make.

\section{Weltanschauung}

Over 25 years ago, Rensis Likert talked of "linking pins," individuals who are particularly valuable to an organization because they are able to bridge gaps in the perceptions and attitudes of various groups and facilitate understanding among those with different "world views."1 Managers who can listen carefully to the concerns of servers, for in stance, and explain those issues clearly to the director of food ser vice, or managers who can help frustrated front-desk personnel see the situation from the customer's viewpoint, are recognized as valua ble employees. The term "world view" today has a new connota tion - that of the gulf that is cre ated as managers work in foreign facilities and deal with cross-cul tural differences. In the communi cation classroom, Likert's concern for linkage translates into the de velopment of empathy - an indi-

IRensis Likert, New Patterns of Management (New York: McGraw-Hill, 1961), p. 113. 


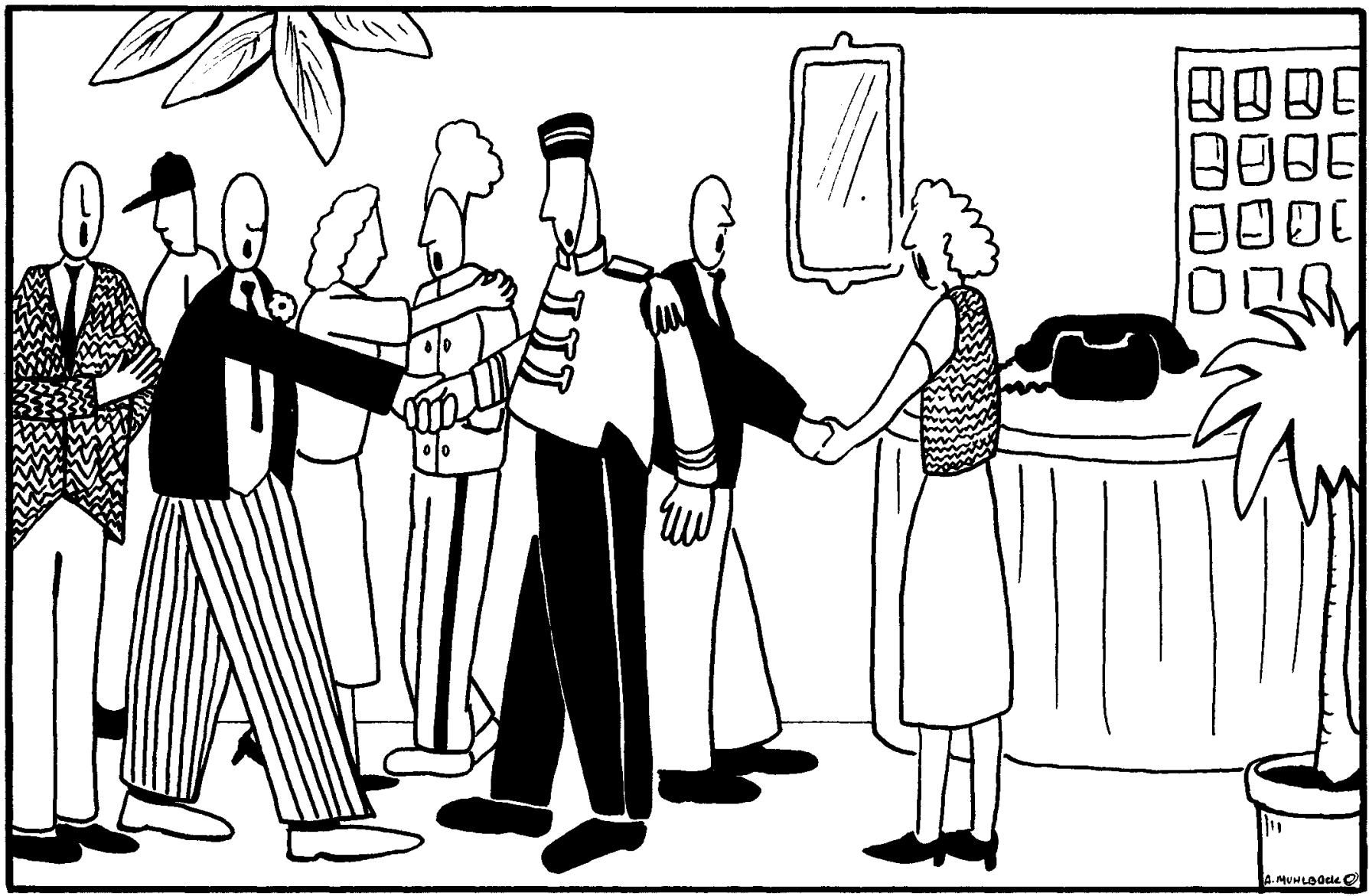

vidual's ability to see things from the other person's point of view in an open, nonjudgmental way. ${ }^{2}$

Empathy is as much an attitude as a skill. We can teach individuals to analyze their reader, to listen carefully to the customer, and to employ paraphrasing and perception checking as communication skills. ${ }^{3}$ Unless students have a basic concern for the welfare of their colleagues, however, their communication skills will never really develop. In a survey of Fortune 500

"Gerald Egan, You and Me: The Skills of Commun cating and Relating to Others (Belmont, NY: Wadsworth, 1977).

"See: Judi Brownell, "Listening: The Toughest Management Skill," The Cornell Hotel and Restaurant Administration Quarterly, 27, No. 4 (February 1987), pp. 64-71. companies, empathy was reported to be one of the most important management characteristics. ${ }^{4}$ It has also been shown to be the most difficult to instill. ${ }^{5}$

How do we teach attitudes or move students from an egocentric position to one of sincere concern for others? Attitudes develop over time in response to an environment in which certain behavior is valued. The student-teacher relationship in the communication classroom can influence this attitude development. As students participate in experiential activities and as they present their ideas and opinions both orally and in writing, the communication classroom becomes a laboratory in which students are

"Gary T. Hunt and Louis P. Cusella, "A Field Study of Listening Needs in Organizations," Communication Education, 32, No. 4 (October 1983), p. 394.

${ }^{5}$ Hunt and Cusella, loc. cit. able to see immediately the effect their behavior has on others in the class. ${ }^{6}$ As an open, "safe" environment, the classroom provides students an opportunity to recognize and appreciate individual differences.

If empathy is at the heart of a new management focus, the concept of trust is its soul. ${ }^{7}$ We recognize that for personal growth and risk-taking, it is essential not only to

'For an example of a laboratory approach, see: Michele Tolela Myers and Gail E. Myers, Managing by Communication: An Organizational Approach (New York: McGraw-Hill, 1982).

${ }^{7}$ For example, see: Thomas H. Melohn, "How to Build Employee Trust and Productivity" Haroard Business Review, 62, No. I (January-February 1983), pp. 55-66; or: Richard E. Walton, "From Control to Commitment in the Workplace," Har vard Business Review, 64, No. 2 (March-April 1985), pp. 77-84. 


\section{EXHIBIT 1}

Traditional and expanded views

of communication education

\section{Traditional view}

1. Concerned with effective communication

2. Necessary skills:

- Analyzing reader or listener

- Establishing credibility with audience

-Organizing ideas

-Developing ideas with appropriate evidence and support

- Expressing ideas clearly and concisely

_Using appropriate language

- Using appropriate tone

Expanded view

1. Concerned with effective leadership

2. Employs traditional skills, plus the following:

-Establishing empathy with others

- Creating atmosphere of trust through consistent actions

- Using intuition and logic to solve problems

-Assessing the effects of one's behavior on others

- Adapting to a variety of individuals and contexts

- Moving from a specialized area to a more general view

- Showing a sincere interest in others' welfare understand your peers and coworkers, but also to trust them. Gordon Shea proposes that trust is the "ultimate intangible." He adds that trust:

... has no shape or substance, yet it empowers our actions. And its presence or absence can govern our behavior as if it were a tangible force.

.. Trust is a social-survival mechanism that allows us to cooperate for mutual benefit."

\section{Collaboration}

One of the best ways to encourage interpersonal trust in the classroom is by emphasizing collaborative rather than competitive approaches." How inconsistent it is for the student to spend an academic career learning to achieve through competition, only to be told upon graduation that the primary goal of management is to make each employee a team player!

Kenneth Blanchard, author of The One-Minute Manager, tells the story of a fourth-grade teacher who was quizzing her students on the names of state capitals. "Why not let them work together and share their information?," Blanchard suggested. "Better yet, why not let them use a dictionary?" "Well," the teacher snapped, "isn't it obvious? If I let them do that, everyone would get the right answer."

Opportunities abound in communication courses for building a collaborative spirit as students work together and as their interactions are observed and processed. Curtis Tarr, dean of the Johnson Graduate School of Management at Cornell University, believes that only cooperation "gives way to tactics that guarantee success." He adds that it is important for young

${ }^{x}$ Gordon Shea, Building Trust in the Workplace (New York: American Management Association. 1984), p. 12.

"Shea, pp. 13- 14.

"*."Alfie Kohn, "How to Succeed Without Even Vying," Psychology Today, September 1986, p. 28.

"Kenneth Blanchard, "Putting the One-Minute Manager to Work." (presentation in Dallas, 'Iexas, January 18. 1987). people to "work with and help fellow students in an atmosphere of mutual support."' When this attitude is carried over into a hotel or restaurant job, it forms that basis for an emphasis on service.

If one role stands out for managers in the next decade, it is that of coaching. Eric Allenbaugh writes that coaching is a "positive process of enabling strengths to be used productively." 13 It is the ongoing, face-to-face process of influencing behavior in which manager and employee collaborate in improving the employee's job performance. As Tom Peters and Nancy Austin put it in their best-selling book, $A$ Passion for Excellence, coaching is leadership that pulls people together and encourages them to "step up to responsibility and continued achievement." Barbara Hoover, director of personnel for the Dallas Hyatt Regency, recently noted that the hotel had come to depend on the coaching relationship for the bulk of its training. Effective coaches are able to use every contact with employees as an opportunity to improve their effectiveness. Peters and Austin explained that coaches find and nurture "champions"-outstanding employees-by building personal relationships with them.

Coaching requires not only skill but also interpersonal sensitivity. If we can assume that the coach-manager has developed both empathy and trust, we can move to look at other, more observable requirements for excellence in coaching:

\footnotetext{
"Curtis W. 'Tarr, "How to Humanize MBAs." Fontune, March 31, 1986, pp. 153-154.

"Eric Allenbaugh, "Coaching: A Management tool for More Effective Work Performance." Management Reviezu, 27, No. 5 (May 1983), p. 22.

$1+$ Thomas H. Peters and Nancy Austin, A Passzon for Excellence: The Leudership Difference (New York: Random House. 1985), p. 384
} 
extensive self-monitoring, the ability to provide constructive feedback, and behavioral flexibility. Individuals who coach must be sensitive to the impact their actions and responses have on others. They must have mastered behavioral flexibility - the use of response styles for different employees and different situations.

Students can practice responding to a wide range of situations in the communication classroom. They can discuss and argue and thereby learn that every communication response makes a difference. As instructors, we can not only convince future managers that coaching is important, but we can also help them coach well.

The hospitality industry is not the only one to recognize the importance of interpersonal sensitivity. A 1986 story in Business Week noted that "influential executives and alumni don't like the Harvard Business School's reputation for turning out cold, number-crunching automatons." 15 These alumni would like to see the quantitative aspect balanced by a greater concern for the human element in organizations.

Weston Agor noted a parallel development: managers are beginning to rely more heavily on intuition in making some of their most important decisions. ${ }^{16} \mathrm{He}$ believes that individuals in top-level management positions will need more right-brain skills-including intuition-than ever before, as they put increasing emphasis on developing human resources. Those pursuing careers in the service industry in particular may benefit from learning to cope with less structure and resolving problems by using

15" Remaking the Harvard B-School," Business Week, March 24, 1986, pp. 54-57.

"Weston H. Agor, "Using Intuition to Manage Organizations in the Future," Business Horizons, July-August 1984, pp. $49-54$. hunches in addition to hard data. Effective hospitality managers realize that anyone can learn to follow the rules; it's knowing when (and how) to disregard them that often makes the difference.

\section{The Communication Classroom}

Finally, as the communication classroom serves as a context in which students develop collaborative methods and practice coaching skills, it also emerges as a place where specialists congregate. Communication courses use as their substance the entire range of business concerns. It is logical, therefore, that this environment provides one of the few places where students can view issues from multiple perspectives. Years ago, Elwood Murray wrote of the importance of a relational orientation in decision-making. ${ }^{17} \mathrm{He}$ stressed that specialists working too close to their areas of expertise were dangerous organizational decisionmakers. Only managers who are able to see the consequences of their choices on all parts of the system can act wisely. The communication classroom is a place where such consequences can be explored. It is also a place where ethical questions can be raised. Clearly, all faculty members share the re-

\footnotetext{
${ }^{17}$ Elwood Murray, "Future Directions in Communication Research: An Assessment of the Possible Use of Analogues," The Journal of Communication, XI (March 1961), pp. 3-12,33; and Elwood Murray, "Communicating and Relating: Undoing the Fragmentations," Elc., A Review of General Semantics, 33 (December 1976), pp. 423-443.
}

sponsibility for helping students work through the implications of the decisions they make. As Tarr stated so convincingly, faculty members must "consider the time they spend with students as the most important dimension of their professional lives." ${ }^{8}$ If we are to affect students' values and behavior, we must assume a mentoring role. Opportunities to help students explore important ethical issues must be recognized both inside and outside of the classroom. The interdisciplinary nature of their subject enables communication educators to share heavily in this responsibility.

As we search for our future leaders, we look for effective communicators. But our understanding of what management communication means for the hospitality field has changed since our first recruiter's visit. Students will always benefit from being able to speak articulately and to organize a memo. But the competitive, aggressive individual may no longer be as welcome as in the past. Managers and leaders are finding that more can be accomplished through collaboration than competition, and that managers can function as coaches by developing sensitivity, along with technical expertise. In this evolution, our students stand to gain personally and professionally. Those who have had caring instructors, who have been challenged to confront difficult questions in the classroom, and who have been encouraged to use their imagination as well as their calculators-these are the leaders we need. And the communication educator plays a vital role in their development.

IsTarr, loc. cit. 